\title{
The RXR agonist LG100268 causes hepatomegaly, improves glycaemic control and decreases cardiovascular risk and cachexia in diabetic mice suffering from pancreatic beta-cell dysfunction
}

\author{
J.M. Lenhard ${ }^{1}$, M. E. Lancaster ${ }^{1}$, M. A. Paulik ${ }^{1}$, J. E. Weiel ${ }^{1}$, J. G. Binz ${ }^{1}$, S. S. Sundseth ${ }^{2}$, B. A. Gaskill ${ }^{3}$, \\ R.M. Lightfoot ${ }^{3}$, H. R. Brown ${ }^{4}$ \\ ${ }^{1}$ Department of Metabolic Diseases, Glaxo Wellcome Inc., Research Triangle Park, North Carolina, USA \\ ${ }^{2}$ Department of Functional Genetics, Glaxo Wellcome Inc., Research Triangle Park, North Carolina, USA \\ ${ }^{3}$ Department of Medicines Safety Evaluation, Glaxo Wellcome Inc., Research Triangle Park, North Carolina, USA \\ ${ }^{4}$ Department of Strategic Toxological Sciences, Glaxo Wellcome Inc., Research Triangle Park, North Carolina, USA
}

\section{Abstract}

Aims/hypothesis. Although retinoid $\mathrm{X}$ receptor (RXR) and peroxisome proliferator activated receptor- $\gamma$ (PPAR $\gamma$ ) agonists have antidiabetic effects in hyperinsulinaemic animals, little information exists on their effects after pancreatic beta-cell failure. Thus, we examined if RXR and PPAR $\gamma$ agonists alter distinct metabolic pathways in animals suffering from impaired insulin secretion.

Methods. Adverse side effects and antidiabetic responses were measured in $d b / d b$ mice treated from 14-16 weeks of age with the RXR agonist, LG100268, and/or the PPAR $\gamma$ agonists, BRL49 653 or GW1929. Results. In animals treated with LG100268 or BRL49653, serum glucose, glycohaemoglobin and the cardiovascular risk factor, fibrinogen, decreased to the same extent. Both of these agonists were equally effective at increasing insulin accumulation in beta cells, although neither agent had an effect on serum insulin concentrations. In contrast, the RXR agonist was less effective than the PPAR $\gamma$ ag- onists at lowering serum triglycerides and non-esterified fatty acids and increasing interscapular brown fat and body weight. Further, LG100268 increased serum alkaline phosphatase and liver mass, hepatic fat accumulation, lauric acid hydroxylase activity, catalase-immunostaining and peroxisomal number more than the PPAR $\gamma$ agonists. Moreover, co-treatment with the RXR and PPAR $\gamma$ agonists reduced glucose, triglycerides, non-esterified fatty acids and cholesterol more than either agent alone.

Conclusion/interpretation. These data suggest 1) $\mathrm{RXR}$ and $\operatorname{PPAR} \gamma$ agonists decrease islet degeneration, cardiovascular risk and cachexia during later stages of diabetes, 2) RXR agonists are less effective than PPAR $\gamma$ agonists at decreasing serum lipids and causing weight gain and 3) RXR agonists have a more pronounced effect on liver metabolism (e.g. peroxisome accumulation and hepatomegaly) than PPAR $\gamma$ agonists. [Diabetologia (1999) 42: 545-554]

Keywords RXR, PPAR $\gamma$, Diabetes, dyslipidemia, cachexia, hepatomegaly, cardiovascular, islets.
Received: 13 July 1998 and in final revised form: 4 December 1998

Corresponding author: J. M. Lenhard, Dept. of Metabolic Diseases, Glaxo Wellcome Inc., 5 Moore Drive, Research Triangle Park, NC 27709, USA

Abbreviations: PPAR $\gamma$, Peroxisome proliferator activated receptor $\gamma$; RXR, retinoid X receptor; NEFA, non-esterified fatty acid; GHB, glycohaemoglobin; AST, aspartate aminotransferase; ALP, alkaline phosphatase; LDH, lactate dehydrogenase; BUN, blood urea nitrogen; IBAT, interscapular brown adipose tissue; LAH, CYP4A-lauric acid hydroxylase.
Peroxisome proliferator activated receptor $\gamma$ $(\operatorname{PPAR} \gamma)$ and retinoid $\mathrm{X}$ receptor $\alpha(\mathrm{RXR} \alpha)$ bind to DNA as heterodimer partners (ARF6) and regulate ligand-activated transcription of various genes involved in lipid and carbohydrate metabolism [1, 2]. Various agents identified as PPAR $\gamma$ agonists, such as BRL49653, troglitazone and GW1929, improve insulin action [3-7], glucose up-take and glucose-stimulated insulin release [8] in several rodent models of Type II (non-insulin-dependent) diabetes mellitus. Similarly, RXR agonists (e.g. LGD1069 and LG100268) improve glucose tolerance and decrease hyperglycaemia, hypertriglyceridaemia and 
hyperinsulinaemia in $d b / d b$ and $o b / o b$ mice $[9,10]$. Thus, identification of agonists that activate RXR or PPAR $\gamma$ may lead to novel agents for treating Type II diabetes. Although activation of the PPAR $\gamma /$ RXR heterodimer complex is believed to result in antidiabetic efficacy, it is not clear if distinct metabolic pathways are affected by agonists for either receptor in vivo.

Many diabetic patients are at risk for cardiovascular disease and, in some cases, the prevention or treatment of diabetes might reduce the risk of cardiovascular disease. Serum insulin, lipids (e.g. cholester$\mathrm{ol}$ and triglycerides) and blood-clotting factors (e.g. fibrinogen) may all have a role in the development of cardiovascular risk factors, such as hypertension, dyslipidaemia and obesity. As several risk factors are associated with diabetes, perhaps multiple antidiabetic agents with distinct mechanisms of action will be needed to treat cardiovascular disease. Thus, an understanding of how RXR and PPAR $\gamma$ agonists affect these risk factors could be useful in the treatment of cardiovascular disease.

Studies involving genetic models of diabetes suggest that early in the course of the disease, hyperinsulinaemia is a causative factor of tissue insulin resistance $[11,12]$. In the C57BL/KsJ strain of $d b / d b$ mice, insulin is transiently over-secreted, reaching a maximum serum concentration by 8 to 10 weeks of age [11]. In this strain, over-secretion of insulin leads to beta-cell dysfunction, characterized by beta-cell necrosis, insulinopenia and severe diabetes [12]. By 3 months of age, male $\mathrm{C} 57 \mathrm{BL} / \mathrm{KsJ} d b / d b$ are losing weight and their death rate increases $[11,12]$.

Although several studies suggest PPAR $\gamma$ and RXR agonists improve glycaemic control and pancreatic function $[7-9,13]$ possibly by decreasing islet fat content [14], the effects of these agents on diabetes during beta-cell failure in older animals (i.e. after the onset of cachexia) is not clear. Further, a comparison has not been made of the effects of PPAR $\gamma$ and RXR agonists on body and organ weight, cardiovascular risk factors (non-esterified fatty acids, cholesterol and fibrinogen) or liver function. Thus, in our study, we examined how PPAR $\gamma$ (BRL49653 and GW1929) and RXR (LG100268) agonists altered these metabolic variables in 16-week-old C57BL/ $\mathrm{KsJ}-d b / d b$ mice.

\section{Materials and methods}

Materials. The compounds LG100268, BRL49653 and GW1929 (compound 18, [5]) were synthesized by the Medicinal Chemistry Department at GlaxoWellcome Inc. (Research Triangle Park, North Carolina). We chose BRL49653 and LG100268 for these studies because a comparison of both agents has been reported previously using younger (47 day) hyperinsulinaemic mice [9]. Moreover, a novel PPAR $\gamma$ agonist, GW1929, which is a tyrosine analogue that does not belong to the thiazolidinedione class of compounds [5], was included for comparison in these studies. The structure of these ligands and potency in transfection assays for RXR and PPAR $\gamma$ have been recorded by others $[3,5,9]$.

Experimental animal protocol. Male C57BL/KsJ- $+d b /+d b$ mice (Jackson Labs, Bar Harbor, Me., USA) matched for age and weight were housed five animals a cage at $22^{\circ} \mathrm{C}$ and $50 \%$ relative humidity with a $12 \mathrm{~h}$ light and dark cycle and fed chow diet (NIH R\&M/Auto 6F-Ovals 5K67, PMI Feeds, Richmond, Ind., USA). Animals (12 animals in a group) starting at 14 weeks of age were orally gavaged once daily (0800-0900 hours) with $0.05 \mathrm{~mol} / \mathrm{l} \mathrm{N}$-methylglucamine (control), $20 \mathrm{mg} / \mathrm{kg}$ BRL49 653 in $0.05 \mathrm{~mol} / 1 \mathrm{~N}$-methylglucamine, $10.0 \mathrm{mg} / \mathrm{kg} \mathrm{GW} 1929$ in $0.05 \mathrm{~mol} / 1 \mathrm{~N}$-methylglucamine, and/or $10 \mathrm{mg} / \mathrm{kg} \mathrm{LG} 100268$ in $0.05 \mathrm{~mol} / \mathrm{l} \mathrm{N}$-methylglucamine. The doses for BRL49653 and LG100268 were selected because preliminary 2-week dose-response experiments in $d b / d b$ mice showed these doses were most effective at lowering serum glucose. For comparative purposes, the same dose $(10.0 \mathrm{mg} / \mathrm{kg})$ of GW1929 and LG100268 was chosen. After 2 weeks of dosing, the animals were anaesthetized with isofluorane, blood was drawn by cardiac puncture and non-fasting measurements of glucose, total cholesterol, triglycerides, non-esterified free fatty acids (NEFAs), glycerol, alkaline phosphatase, insulin and glycohaemoglobin (GHB) were obtained. All blood chemistry tests, with the exception of GHB, insulin and fibrinogen, were determined using an automated chemistry analyser (Technicon Axon, Tarrytown, N. Y., USA). Glycohaemoglobin measurements were done with Columnmate Analyzer (Helena Instruments, Beaumont, Tex., USA). Insulin concentrations in serum were measured by chemiluminescence using an Origen Analyzer (Igen, Gaithersburg, Md., USA). Fibrinogen was measured following published procedures [15]. Body weights were recorded at the beginning and end of the study. Upon necropsy, liver, heart and interscapular brown fat (IBAT) were excised and the respective weights recorded. In addition, five animals from each treatment group were placed in metabolic cages for $48 \mathrm{~h}$ at the end of the study for quantitation of food and water consumption and waste production. Unless stated otherwise, all data were calculated as the mean and standard error from experiments on 12 animals per treatment group. Two-tailed tests were done to calculate $p$ values. This research complied with the principles of laboratory animal care (NIH publication No. 86-23, revised 1985) and company policy on the care and use of animals and related codes of practice.

Histology. Monoclonal antibody to human insulin, MAB391P, derived from mouse ascites fluid was purchased from Innovex Biosciences (Richmond, Calif., USA). Formalin-fixed, paraffin embedded, deparaffinized tissue sections of pancreas from control and treated animals were incubated for $20 \mathrm{~min}$ with prediluted primary antibody after quenching endogenous peroxidase activity with $3 \% \mathrm{H}_{2} \mathrm{O}_{2}$ and blocking with manufacturer-supplied blocking reagent for $10 \mathrm{~min}$. Phosphate buffered saline was used as a negative control. After 20 min incubation with manufacturer-supplied secondary antibody, chromagen AEC was added for $5 \mathrm{~min}$, rinsed and counter-stained with aqueous haematoxylin according to the manufacturer's instructions using the Innovex Histo-Stat, 2-step Peroxidase detection kit (Innovex Biosciences). At least three representative islets were microscopically examined from each section and evaluated for regularity of islet contours, islet granularity, degree of granule staining and islet cell degeneration. To quantify the insulin content in pancreas, immuno-stained islet sections from each treatment group (three animals per group) were ex- 
amined by random stage selection of the first 3 intact islets from each animal $(n=9)$. Pax-it images were captured at identical magnifications and colour and contrast settings. The images were analysed using the MCID version 3.1 image analysis software and 32-bit colour display program option (Imaging Research, St. Catherines, Ontario, Canada). Islets with the most prominent chromagen label were selected for measuring insulin content. Measurements included total target area (total area of cells/grains within the region of interest containing the maximum insulin) and proportional area (total target/grain area relative to scan area). The latter measurement adjusts for differences in islet size. For immunohistochemical examination of catalase, formalin-fixed, paraffin-embedded sections of liver were deparaffinized and hydrated. Heat epitope retrieval was by DAKO Target Retrieval Solution. Sections were stained with 1:20-diluted polyclonal sheep anti-catalase (Biodesign International, Kennebunk, Me., USA) antibody for $1 \mathrm{~h}$. Immunolabelling was by Innovex Stat-Q, 3-step detection kit and 3,3-diaminobenzidine (DAB) was used as the chromogen. Staining in the absence of primary antibody was used as a negative control. Liver fixation and oil-red $\mathrm{O}$ staining was done according to standard protocols [16]. At least three representative liver sections were examined microscopically from each treatment group and evaluated for catalase and oilred $\mathrm{O}$ staining. Photographs of representative islets and liver sections from each group were taken at the same magnification using a Nikon Microphot-FXA microscope, Sony Model DXC-960MD colour video camera and Pax-it image capture system (Midwest Information Systems, Franklin Park, Ill., USA). Transmission electron microscopy was done using standard protocols [17]. In sum, $1 \mathrm{~mm}$ cubes of formalin-fixed liver tissue were post-fixed for $24 \mathrm{~h}$ in $2.5 \%$ glutaraldehyde in $0.1 \mathrm{~mol} / \mathrm{l}$ sodium cacodylate buffer $(\mathrm{pH} 7.3$ ) before processing and embedding in Spurr resin. Semi-thin sections were cut on a Reichert-Jung Ultracut E ultramicrotome (Reichert-Jung, Vienna, Austria), stained with toluidine blue and viewed with a light microscope. Ultra-thin sections were stained with lead citrate and uranyl acetate and examined with a Jeol 100C transmission electron microscope (Jeol, Tokyo, Japan).

Biochemistry. Lauric acid hydroxylase activity was determined by using published procedures [18]. Protein measurements were determined using the BCA-Protein Assay according to the manufacturer's specifications (Pierce, Rockford, Ill., USA).

\section{Results}

Insulin, glucose and GHB responses. As BRL49653 [7], GW1929 [5] and LG100268 [9] are agonists of the PPAR $\gamma /$ RXR heterodimer complex, which decrease serum glucose concentrations in hyperinsulinaemic animals, we were interested to find if these agents could also decrease hyperglycaemia in mice that develop pancreatic beta-cell dysfunction and cachexia. To confirm that the 16-week-old $d b / d b$ mice used in our study had a defect in insulin secretion, we compared the serum insulin, glucose and GHB concentrations of 6- and 16-week-old $d b / d b$ mice. As expected, due to progression of the disease, the older animals had less insulin, more glucose and more GHB in serum than the younger animals (Table 1).

Based on preliminary experiments, we observed full therapeutic effects on glucose at $3 \mathrm{mg} / \mathrm{kg}$ for
Table 1. Antidiabetic effects of RXR and PPAR $\gamma$ agonists in $d b / d b$ mice

\begin{tabular}{lcll}
\hline & $\begin{array}{l}\text { Insulin } \\
(\mathrm{pmol} / \mathrm{l})\end{array}$ & $\begin{array}{l}\text { Glucose } \\
(\mathrm{mmol} / \mathrm{l})\end{array}$ & $\%$ GHB \\
\hline 6-wk Control & $2130 \pm 315$ & $20.8 \pm 2.5$ & $6.60 \pm 0.44$ \\
16-wk Control & $235 \pm 90$ & $39.6 \pm 1.7$ & $14.07 \pm 0.46$ \\
16-wk LG100268 & $265 \pm 85$ & $\begin{array}{l}22.5 \pm 2.6 \\
(<0.0001)\end{array}$ & $\begin{array}{l}11.10 \pm 0.26 \\
(0.0003)\end{array}$ \\
16-wk BRL49653 & $170 \pm 70$ & $22.0 \pm 2.2$ & $10.93 \pm 0.57$ \\
& $(0.20)$ & $(<0.0001)$ & $(0.0017)$ \\
16-wk GW1929 & $205 \pm 75$ & $30.7 \pm 1.5$ & $11.25 \pm 0.55$ \\
& $(0.38)$ & $(0.003)$ & $(0.005)$ \\
LG100268+ GW1929- & $245 \pm 85$ & $15.5 \pm 1.7$ & $10.41 \pm 0.27$ \\
16 wk & $(0.38)$ & $(<0.0001)$ & $(0.0004)$ \\
\hline
\end{tabular}

Numbers in parentheses denote the statistical significance $(p$ value) of the experimental groups relative to the 16-week-old control group calculated using Student's $t$ test. wk, week

BRL49653 in $d b / d b$ mice, $5 \mathrm{mg} / \mathrm{kg}$ for GW1929 in ZDF rats and $5 \mathrm{mg} / \mathrm{kg}$ for LG100268 in $o b / o b$ mice $([5,7,9]$ J. M. Lenhard, unpublished observation). Further, at maximum effective doses, PPAR $\gamma$ and RXR agonists exert a full therapeutic effect within 7 days in $d b / d b$ mice $([5,7,9] \mathrm{J} . \mathrm{M}$. Lenhard, unpublished observation). Thus, to determine if PPAR $\gamma$ and RXR agonists could decrease hyperglycaemia in older mice, the animals were treated between 14 and 16 weeks of age with $20 \mathrm{mg} / \mathrm{kg}$ BRL49653, $10 \mathrm{mg} / \mathrm{kg}$ GW1929, and $10 \mathrm{mg} / \mathrm{kg} \mathrm{LG} 100268$. At the end of treatment, serum concentrations of glucose, GHB and insulin were determined. Serum glucose and GHB were significantly decreased after treatment with BRL49653, LG100268 and GW1929 (Table 1). To determine if the response to RXR agonists could be further enhanced by treatment with PPAR $\gamma$ agonists, animals were treated with LG100268 in the presence or absence of GW1929. As observed for 7- to 9-week-old $d b / d b$ mice [9], combination treatment with both agonists in 14- to 16-week-old mice was more efficacious on serum glucose concentrations than any of the compounds alone (Table 1).

Given that serum insulin concentrations remained unchanged in each of the treatment groups, we were interested in determining if RXR or PPAR $\gamma$ agonists influenced beta-cell insulin content. Thus, after animals were treated for 2 weeks with LG100268 and BRL49653, the pancreata were removed, fixed and processed for immunocytochemistry using prepared antibodies to insulin. As shown in the micrograph in Fig. 1 and Table 2, there was a large increase in insulin-content in islets from animals treated with LG100268, BRL49653 and GW1929 compared with the control mice.

Lipid responses. Although PPAR $\gamma$ and RXR agonists decrease serum triglycerides in hyperinsulinaemic animals, the hypolipidaemic effect of these agents is not 


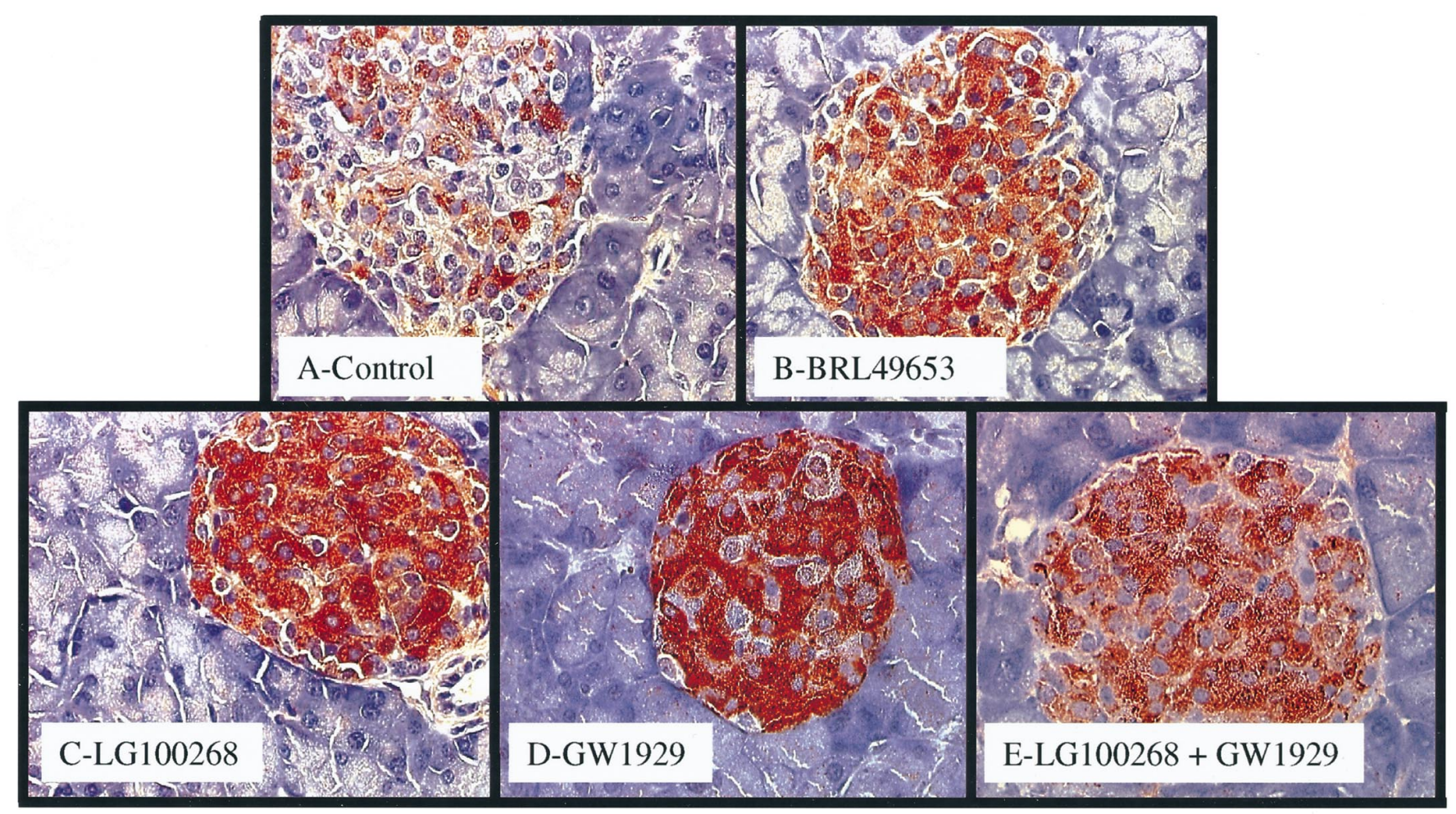

Fig. 1 A-E. Islet-staining using antibodies to insulin. Pancreatic islets were fixed, sectioned and stained for insulin from $d b$ / $d b$ mice that were treated from 14 to 16 weeks of age with $(\mathbf{A})$ N-methylglucamine (control), (B) BRL49653, (C) LG100268, (D) GW1929, or (E) LG100268 and GW1929. The micrographs are representative data obtained from histological analysis of five animals per treatment group and at least three islets per animal

Table 2. Insulin content in islets from 16 week old $d b / d b$ mice

\begin{tabular}{llll}
\hline & $\begin{array}{l}\text { Mean } \\
\text { (Immunostaining } \\
\text { density) }\end{array}$ & Variance & $p$ \\
\hline Control & 0.0609 & 0.0050 & \\
LG100268 & 0.1817 & 0.0119 & 0.0005 \\
BRL49653 & 0.2207 & 0.0167 & 0.0002 \\
GW1929 & 0.1424 & 0.0065 & 0.0169 \\
LG100268 + GW1929 & 0.2242 & 0.0187 & 0.0376 \\
\hline
\end{tabular}

Insulin was quantified by image analysis of immunostained islets as described in the Methods. Statistics were calculated using paired Student's $t$ test $(n=9)$

known in animals with beta-cell degeneration. Moreover, the influence of selective-RXR agonists on NEFAs and glycerol in rodent models of diabetes has not been reported. Thus, we measured how BRL49653, GW1929 and LG100268 alter accumulation of serum triglycerides, NEFAs, cholesterol and glycerol in 16-week-old $d b / d b$ mice. In contrast to their effect on glucose, BRL49653 and GW1929 were much more efficacious than LG100268 at lowering serum triglycerides and NEFAs in these mice (Table 3 ). When used alone, however, BRL49653, GW1929 and
LG100268 had little influence on serum cholesterol and glycerol. To determine if the response to RXR agonists could be further enhanced by treatment with $\operatorname{PPAR} \gamma$ agonists, animals were treated with LG100268 in the presence or absence of GW1929. Co-treatment with GW1929 and LG100268 was more effective than either compound alone at decreasing the triglyceride, NEFA, cholesterol and glycerol concentrations in the serum (Table 3 ).

Clinical toxicology. To compare the relative safety of LG100268 and BRL49653, we did liver [aspartate aminotransferase (AST) and alkaline phosphatase (ALP)], heart/muscle [lactate dehydrogenase (LDH)] and kidney [blood urea nitrogen (BUN)] biochemical tests (Table 4). Since this was a preliminary screen, specific isozymes of ALP and LDH were not analysed. Little difference in the serum concentrations of AST, LDH or BUN was observed when N-methylglucamine (control), LG100268-treated and BRL49653-treated animals were compared (Table 4). Serum ALP was, however, raised ninefold after treatment with LGD100268 and threefold after treatment with BRL49653 compared with control mice (Table 4). To analyse further the safety of LG100268 and BRL49653, we measured the serum concentration of fibrinogen, a blood-clotting factor synthesized by the liver and associated with increased cardiovascular risk. Both LG100268 and BRL49653 decreased the serum concentration of fibrinogen (Table 4).

Body and organ weights, food and water consumption. The PPAR $\gamma$ agonists are anabolic agents that 
Table 3. Effects of RXR and PPAR $\gamma$ agonists on plasma lipids in $d b / d b$ mice

\begin{tabular}{lllll}
\hline & $\begin{array}{l}\text { Triglycerides } \\
(\mathrm{mmol} / \mathrm{l})\end{array}$ & $\begin{array}{l}\text { NEFAs } \\
(\mathrm{mmol} / \mathrm{l})\end{array}$ & $\begin{array}{l}\text { Cholesterol } \\
(\mathrm{mmol} / \mathrm{l})\end{array}$ & $\begin{array}{l}\text { Glycerol } \\
(\mathrm{mmol} / \mathrm{l})\end{array}$ \\
\hline 6-wk Control & $1.46 \pm 0.14$ & $0.24 \pm 0.03$ & $2.95 \pm 0.35$ & $2.28 \pm 0.32$ \\
16-wk Control & $1.62 \pm 0.06$ & $0.85 \pm 0.07$ & $3.45 \pm 0.15$ & $3.58 \pm 0.22$ \\
16-wk LG100268 & $1.13 \pm 0.08$ & $0.75 \pm 0.05$ & $3.20 \pm 0.25$ & $3.15 \pm 0.22$ \\
& $(0.0002)$ & $(0.11)$ & $(0.21)$ & $(0.07)$ \\
16-wk BRL49653 & $0.85 \pm 0.05$ & $0.39 \pm 0.07$ & $3.30 \pm 0.15$ & $3.37 \pm 0.32$ \\
16-wk GW1929 & $(<0.0001)$ & $(0.0002)$ & $(0.87)$ & $(0.22)$ \\
& $0.96 \pm 0.08$ & $0.44 \pm 0.08$ & $3.20 \pm 0.30$ & $3.80 \pm 0.43$ \\
LG100268 + GW1929 & $(<0.0001)$ & $(0.0006)$ & $(0.21)$ & $(0.28)$ \\
16 wk & $0.73 \pm 0.03$ & $0.29 \pm 0.02$ & $2.55 \pm 0.25$ & $(0.0006)$ \\
\hline
\end{tabular}

The $p$ values in parentheses denote the statistical significance in the experimental group relative to the 16-week-old control group. wk, week

Table 4. Plasma health screens in 16 -week-old $d b / d b$ mice

\begin{tabular}{|c|c|c|c|c|c|}
\hline & $\operatorname{ALP}(\mathrm{U} / \mathrm{l})$ & AST (U/l) & BUN (mmol/l) & LDH (U/l) & FIB $(\mu \mathrm{mol} / \mathrm{l})$ \\
\hline Control & $11 \pm 1$ & $156 \pm 32$ & $5.7 \pm 0.4$ & $423 \pm 80$ & $15.3 \pm 2.5$ \\
\hline LG100268 & $\begin{array}{l}91 \pm 30 \\
(0.005)\end{array}$ & $\begin{array}{l}160 \pm 26 \\
(0.46)\end{array}$ & $\begin{array}{l}5.4 \pm 0.4 \\
(0.16)\end{array}$ & $\begin{array}{l}428 \pm 81 \\
(0.48)\end{array}$ & $\begin{array}{l}9.3 \pm 0.7 \\
(0.014)\end{array}$ \\
\hline BRL49653 & $\begin{array}{l}35 \pm 4 \\
(<0.0001)\end{array}$ & $\begin{array}{l}172 \pm 35 \\
(0.36)\end{array}$ & $\begin{array}{l}7.1 \pm 0.7 \\
(0.0001)\end{array}$ & $\begin{array}{l}418 \pm 57 \\
(0.48)\end{array}$ & $\begin{array}{l}9.6 \pm 1.0 \\
(0.05)\end{array}$ \\
\hline GW1929 & $\begin{array}{l}17 \pm 4 \\
(0.066)\end{array}$ & $\begin{array}{l}213 \pm 37 \\
(0.097)\end{array}$ & $\begin{array}{l}8.5 \pm 0.8 \\
(0.002)\end{array}$ & $\begin{array}{l}660 \pm 131 \\
(0.084)\end{array}$ & ND \\
\hline
\end{tabular}

FIB, fibrinogen; ND, not determined. Numbers in parentheses are $p$ values calculated using Student's $t$ test and denote the statistical significance between the experimental and the control group

promote adipogenesis in vitro and IBAT hypertrophy in vivo $[4,19,20]$. Thus, we investigated how RXR and PPAR $\gamma$ agonists altered body, IBAT, liver and heart weight in vivo. The control animals lost weight between 14 and 16 weeks (Table 5), possibly because of diabetic neuropathic cachexia that results from uncontrolled hyperglycaemia. After treatment with BRL49653 or GW1929, the animals, however, gained weight. When the animals were treated with LG100268 alone or in combination with GW1929, their body weight did not change. When organ weights were examined, IBAT mass increased in the BRL49653-treated and GW1929-treated animals, whereas LG100268 had little affect (Table 5). Although heart weight was greater $(37 \pm 2 \mathrm{mg}$, $p=0.0057)$ in the BRL49653-treated mice when compared with the LG100268-treated mice, these changes were not statistically different than the control animals. In contrast, LG100268 was much more effective than BRL49653 or GW1929 at increasing liver weight (i.e. causing hepatomegaly) relative to controls.

No statistically significant effects on food or water intake or fecal production were observed in any of the treatment groups. Since the treated animals gained more weight than the control animals, this suggests RXR and PPAR $\gamma$ agonists increase feeding efficiency (weight gained/calories consumed) in diabetic mice.

Liver. As observed in the clinic, hepatomegaly is associated commonly with fatty infiltration of the liver and increased serum ALP [21]. Given that treatment with LG100268 increased liver weight (Table 5) and serum ALP (Table 4), we looked for fat accumulation in the liver. As shown in the micrograph in Figure 2, there was a substantial increase in the size and number of oil red O-stained fat droplets in the liver of animals treated with LG100268. Although fat accumulation was also observed in animals treated with BRL49653, these animals had less fat in the liver and their livers weighed less than those treated with LG100268. Furthermore, liver weight and oil red O-staining decreased in animals co-treated with LG100268 and GW1929 compared with those treated with only LG100268.

In rodents, peroxisome proliferators (e.g. clofibrate and Wy-14,643) induce hepatomegaly and increase CYP4A-lauric acid hydroxylase (LAH) activity in the liver by activating PPAR $\alpha[22,23]$. As LG100268 also caused hepatomegaly, we examined, by measuring the conversion of lauric acid into 11-hydroxy lauric acid and 12-hydroxy lauric acid, if treat- 


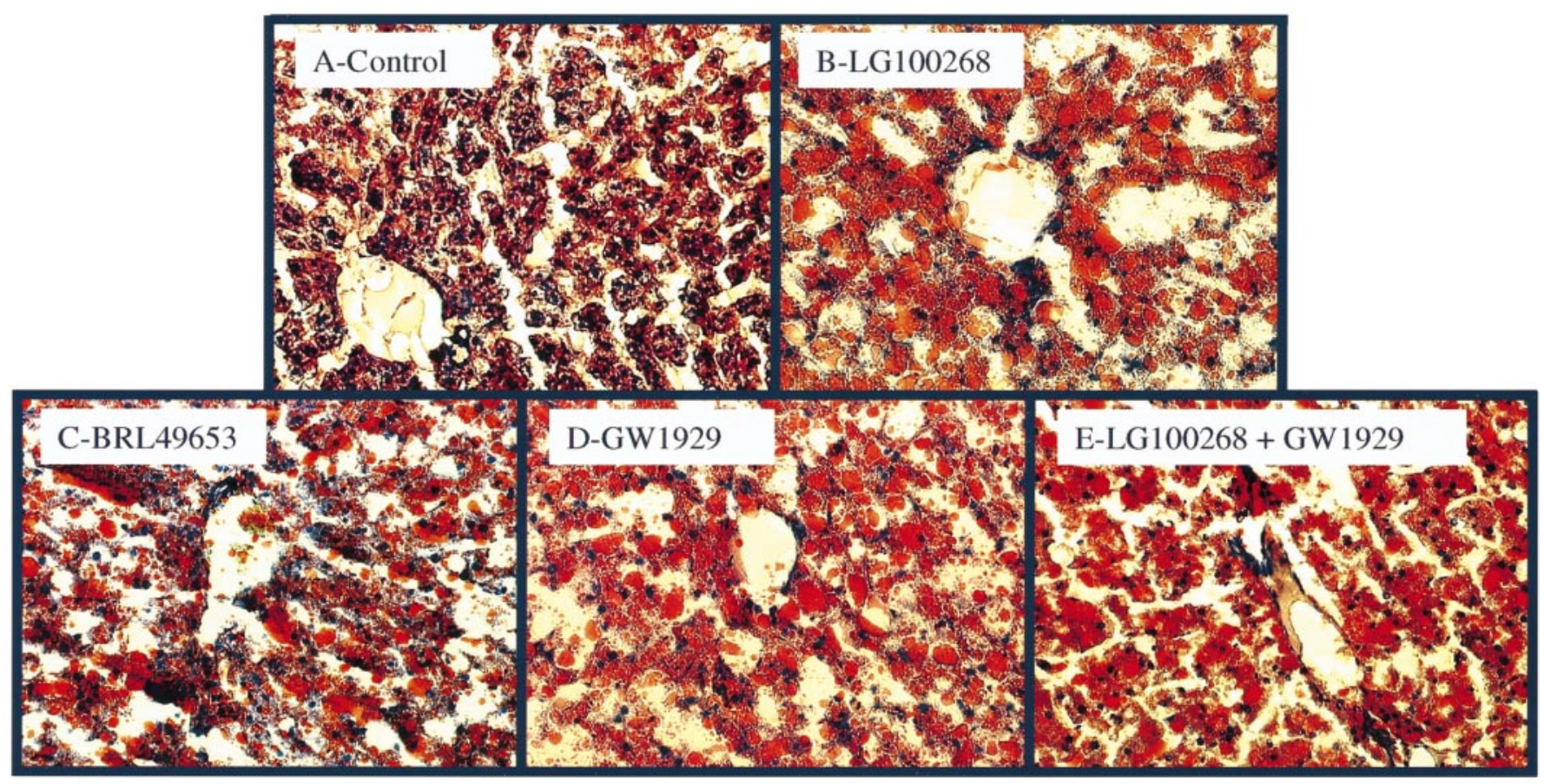

Fig. 2 A-E. Oil red O-staining of liver from $d b / d b$ mice. Liver from animals that were treated with (A) N-methylglucamine (control), (B) LG100268, (C) BRL49653, (D) GW1929 or (E) LG100268 and GW1929 were fixed, sectioned and stained using oil red $\mathrm{O}$. Each micrograph is representative data from histological analysis of five animals per treatment group and at least three liver sections per animal

ment with LG100268 increased LAH activity in the liver. The activity of LAH increased by $350 \%$ in animals treated with LG100268 (Table 6). In contrast, BRL49653 had little affect on LAH activity. Thus, RXR and PPAR $\alpha$ agonists [23] but not PPAR $\gamma$ agonists induce peroxisomal CYP4A LAH activity in the liver.

To further evaluate if LG100268 increased peroxisome proliferation, liver sections were examined by electron microscopy or immunostained for catalase and viewed by light microscopy. Electron microscopic analysis showed LG100268-treated animals had more peroxisomes than control animals (compare Fig. 3A and B). Similarly, the LG100268-treated animals had more catalase in their livers than control animals (compare Fig. 3C and D). Moreover, catalase-immunostaining was particularly prominent in periportal locations in the LG100268-treated animals (data not shown).

\section{Discussion}

Given the pleiotropic nature of diabetes, there is a need for identifying multiple agents with unique properties for treating this disease. Indeed, combination therapy is possibly needed for patients with dia-

Table 5. Effects of RXR and PPAR $\gamma$ agonists on body and organ weight

\begin{tabular}{lllll}
\hline & $\begin{array}{l}\text { Body weight } \\
\text { change }(\mathrm{g})\end{array}$ & $\begin{array}{l}\text { IBAT \% of } \\
\text { body weight }\end{array}$ & $\begin{array}{l}\text { Liver \% of } \\
\text { body weight }\end{array}$ & $\begin{array}{l}\text { Heart \% of } \\
\text { body weight }\end{array}$ \\
\hline Control & $-2.7 \pm 0.7$ & $1.14 \pm 0.10$ & $4.91 \pm 0.19$ & $0.27 \pm 0.01$ \\
LG100268 & $0.5 \pm 0.6$ & $1.05 \pm 0.09$ & $9.12 \pm 0.58$ & $0.25 \pm 0.01$ \\
& $(<0.0001)$ & $(0.15)$ & $(<0.0001)$ & $(0.03)$ \\
BRL49653 & $3.2 \pm 0.7$ & $2.95 \pm 0.48$ & $5.76 \pm 0.45$ & $0.29 \pm 0.01$ \\
GW1929 & $(<0.0001)$ & $(<0.0001)$ & $(0.0019)$ & $(0.14)$ \\
& $3.3 \pm 0.5$ & $2.95 \pm 0.28$ & $5.80 \pm 0.39$ & $0.26 \pm 0.01$ \\
LG100268 + GW1929 & $(<0.0001)$ & $(<0.0001)$ & $(0.0024)$ & $(0.25)$ \\
& $-0.2 \pm 0.8$ & $2.79 \pm 0.48$ & $7.60 \pm 0.47$ & $0.27 \pm 0.02$ \\
$(<0.0001)$ & $(0.32)$ & $(<0.0001)$ & & \\
\hline
\end{tabular}

Body weight change was calculated from animals between 14 to 16 weeks of age. Tissue weights were calculated as a percent of the final body weight at 16 weeks. The $p$ values in par- entheses denote the statistical significance between the experimental and the control group 
Table 6. Effects of BRL49653, GW1929, and LG100268 on liver lauric acid hydroxylase

\begin{tabular}{llc}
\hline & 11-hydroxy lauric acid $\left(\mathrm{nmol} \cdot \mathrm{min}^{-1} \cdot \mathrm{mg}^{-1}\right)$ & 12-hydroxy lauric acid $\left(\mathrm{nmol} \cdot \mathrm{min}^{-1} \cdot \mathrm{mg}^{-1}\right)$ \\
\hline Control & $2.25 \pm 0.17$ & $6.63 \pm 0.78$ \\
BRL49653 & $2.55 \pm 0.35(0.24)$ & $8.73 \pm 1.41(0.12)$ \\
LG100268 & $4.75 \pm 0.54(0.0047)$ & $23.75 \pm 3.59(0.0017)$ \\
GW1929 & $2.67 \pm 0.30(0.047)$ & $9.05 \pm 1.16(0.14)$ \\
LG100268 + GW1929 & $4.72 \pm 0.56(0.0072)$ & $23.90 \pm 0.30(0.0025)$
\end{tabular}

Numbers in parentheses are $p$ values calculated using Student's $t$ test and denote the statistical significance in the differences between the experimental and the control group. Lau- rate hydroxylate activity is expressed as the rate of lauric acid generated per mg of protein betes, since they often have poor responses to singledrug therapy [24]. Thus, in this study we compared how PPAR $\gamma$ (BRL49653 and GW1929) and RXR (LG100268) agonists influence metabolism in $d b / d b$ mice suffering from islet degeneration. Although appreciable beneficial effects of both classes of molecules were observed on serum glucose, GHB, NEFAs, triglycerides, fibrinogen and accumulation of beta-cell insulin, the RXR agonist was less effective than the PPAR $\gamma$ agonists at decreasing serum triglycerides and NEFAs or increasing IBAT and body weight. In contrast, the RXR agonist increased liver weight, hepatocellular lipid and serum alkaline phosphatase more than the PPAR $\gamma$ agonists. These differences suggest that PPAR $\gamma$ and RXR agonists differ in their mode of action and metabolic effects. Alternatively, it is possible the differences in the therapeutic end points are related to differences in relative potency and pharmacokinetic considerations. Given the restricted expression pattern of PPAR $\gamma$ and the ubiquitous expression pattern of RXR we, however, favour the former hypothesis. Further, the data suggest there could be distinct mechanistic advantages, depending on the desired clinical profile, when using a PPAR $\gamma$ or RXR agonist. For example, possibly PPAR $\gamma$ agonists are better as monotherapies for treating diabetic dyslipidaemia or cachexia whereas RXR agonists are best used in combination with PPAR $\gamma$ agonists to further improve antidiabetic efficacy.

Since there were no changes in serum insulin concentrations, the hypoglycaemic effects of RXR and $\operatorname{PPAR} \gamma$ agonists are likely to be the result of enhanced peripheral glucose uptake or suppressed gluconeogenesis or both. Indeed, PPAR $\gamma$ agonists suppress hepatic gluconeogenesis in animal models of diabetes and increase insulin responsiveness of peripheral tissues and isolated cells [4, 6-8], indicating both effects are operative. As RXR agonists stimulate PPAR $\gamma:$ RXR heterodimer activity in cell-based assays [9], it is possible the hypoglycaemic effects of LG100268 also result from enhanced peripheral glucose uptake and suppressed gluconeogenesis. A direct comparison between RXR and PPAR $\gamma$ agonists is, however, needed to determine if there is a differential effect of these agents on glucose uptake and gluconeogenesis.
When 6-week-old control animals were compared with 16-week-old animals that had been treated, serum triglycerides were less and NEFAs were greater in the older animals, suggesting serum NEFAs secondary to triglycerides. As serum change insulin was less in the older animals, it is possible these changes are due to the antilipolytic effect of insulin. The lack of an effect on serum glycerol in treated animals indicates, however, that the decrease in serum NEFAs may not result from the antilipolytic effects of insulin on adipose tissue. Indeed, troglitazone action is proposed to be independent of adipose tissue [25]. Thus, an alternate hypothesis is serum lipids decreased with treatment as a result of a reduction in VLDL-associated and LDL-associated triglyceride production in liver [25].

Fibrinogen is a blood-clotting factor that is synthesized in the liver and, like NEFAs and cholesterol, is an important risk factor for developing cardiovascular disease [26]. Although all-trans-retinoic acid increases serum fibrinogen in vivo [27], the effects of selective RXR and PPAR $\gamma$ agonists on fibrinogen in vivo have not been reported previously. Our data showing LG100268 and BRL49653 decreased serum fibrinogen suggest that RXR and PPAR $\gamma$ are involved in the physiological regulation of fibrinogen. Further, these data suggest RXR and PPAR $\gamma$ agonists may counter-regulate increases in serum fibrinogen mediated by RAR-agonists [27]. Note that non-steroidal anti-inflammatory drugs, which are known to bind and activate PPAR $\gamma$ [28], also lower serum fibrinogen concentrations and suppress platelet aggregation [29]. Furthermore, patients treated with troglitazone benefit from enhanced cardiac output and stroke volume [30]. We propose that this is perhaps, in part, a result of decreased peripheral insulin resistance and plasma fibrinogen, in addition to reduced LDL oxidation [31]. Recently, others have shown that troglitazone treatment is associated with a decrease in plasminogen activator inhibitor concentrations in Type II diabetic patients, indicating this may lead to beneficial effects on fibrinolysis [32]. It is not clear if this is a direct effect of these nuclear receptors on transcriptional regulation, or alternatively, a consequence of increased insulin sensitivity since insulin also lowers serum fibrinogen by inhibiting its synthesis. 


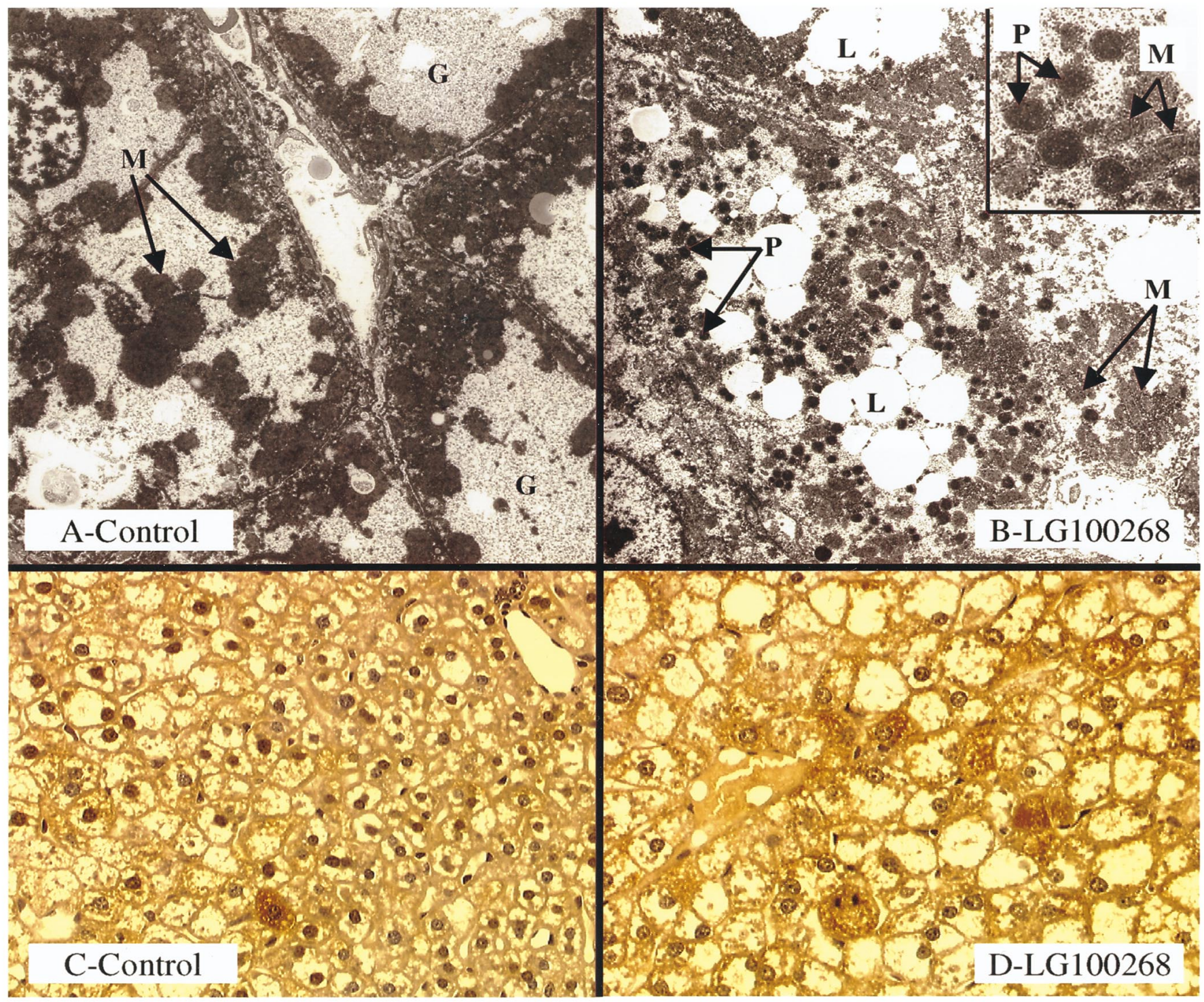

Fig.3 A-D. Electron microscopic analysis and catalase-immunostaining of liver from $d b / d b$ mice. Liver from animals that were treated with $(\mathbf{A}, \mathbf{C}) \mathrm{N}$-methylglucamine (control) or $(\mathbf{B}$ D) LG100268 suspended in N-methylglucamine. Liver sections were prepared for electron microscopy $(\mathbf{A}, \mathbf{B})$ or stained for catalase and analysed by light microscopy $(\mathbf{C}, \mathbf{D})$. The electron micrographs were of samples magnified 3100-fold and the inset was magnified 5100-fold ( $\mathrm{M}$, mitochondria; $\mathrm{P}$, peroxisome; G, glycogen; L, lipid)

Treatment of rodents with agonists for PPAR $\alpha$, such as clofibrate or gemfibrozil, results in decreased plasma triglycerides, hepatomegaly, increased peroxisomal number and induction of several microsomal genes in the liver [33]. Furthermore, trans-activation of reporter genes by PPAR $\alpha$ is stimulated by the addition of both 9-cis retinoic acid and $\operatorname{RXR} \alpha$ [34]. As LG100268 caused hepatomegaly, increased peroxisomal number and induced expression of microsomal lauric acid hydroxylase, we favour the hy- pothesis that the RXR $\alpha / \mathrm{PPAR} \alpha$ heterodimer is a target for LG100268 [10]. Consistent with these observations, others have reported the RXR-selective agonist, SR11237, induces hepatomegaly in rats [35]. Contrary to our results and others $[9,10]$, these authors, however, observed an increase in serum triglycerides after treating rats with SR11237 [35]. It is worth noting that RAR agonists cause hypertriglyceridaemia [36], raising the possibility that SR 11237 used in the earlier studies [35] may have activated the RAR/RXR heterodimer. Alternatively, differences in species (mice vs rats) or the metabolic state of the animals (normal vs diabetic) may explain the differences between these studies. Indeed, speciesspecific effects on liver have been noted for PPAR $\alpha$ agonists. Thus, caution should be exercised in comparing the effects of RXR agonists on hepatomegaly in rodents with clinical toxicity.

There are several possible explanations for the observed increase in serum ALP in the RXR and $\operatorname{PPAR} \gamma$ agonist-treated animals. One hypothesis is 
that activation of RXR and PPAR $\gamma$ may directly induce transcription of ALP in vivo. Although the isozyme responsible for the raised serum ALP was not determined in this study, we have previously shown that activation of this transcription complex suppresses ALP activity in mesenchymal stem cells [19] suggesting this explanation could be incorrect. Alternatively, raised serum ALP could result from increased hepatocyte hypertrophy and lipid accumulation in the liver. Consistent with this idea, patients with fatty livers and hepatomegaly have appreciably higher values for liver-derived ALP than control patients [21]. Since serum ALP concentrations are increased in obstructive jaundice, it is also possible that obstruction of bile flow causes ALP increase.

Treatment of $d b / d b$ mice with GW1929 and BRL49653 resulted in increased IBAT mass, consistent with published results showing an increase in IBAT mass of CD-1 rats treated with BRL49653 [20]. Thus, one proposal is that the antidiabetic effects of PPAR $\gamma$ agonists are mediated, in part, through increased IBAT-mediated thermogenesis [4, 19, 20, 37]. Although RXR forms a heterodimer with PPAR $\gamma$ [1], LG100268 did not, however, cause an increase in IBAT mass in vivo. Thus, it is possible that other tissues, in addition to IBAT, are involved in the antidiabetic effects of agonists for the $\operatorname{PPAR} \gamma / \operatorname{RXR} \alpha$ heterodimer. Consistent with this possibilty, troglitazone has been shown to retain antidiabetic activity in mice whose white and brown fat is virtually eliminated by fat-specific expression of diphtheria toxin A chain [25]. It is also possible that direct activation of PPAR $\gamma$, and not RXR, is necessary for inducing PPAR $\gamma / \mathrm{RXR}$ heterodimer activity and IBAT hypertrophy in vivo.

Although several studies show thiazolidinediones or rexinoids improve insulin secretion in animals before the onset of islet degeneration $[8,9]$, the effects of both agents on islets has not been compared in animals suffering from beta-cell degeneration. Our results show that RXR and PPAR $\gamma$ agonists increase islet insulin content in animals suffering from beta-cell degeneration. This regranulation was probably due to reduced secretion pressure that results from decreasing overstimulation induced by hyperglycaemia. In contrast, thiazolidinedione treatment decreases islet insulin content in animals treated before the onset of islet degeneration [8]. Also in contrast to published results using younger hyperinsulinaemic mice $[6,9]$, none of the antidiabetic agents used changed serum insulin concentrations in the older animals. Thus, the effects of these agents on islets can vary depending on progression of the disease (i. e. islet insulin content is decreased by early treatment and increased by later treatment in disease progression). Moreover, these data show that RXR agonists remain efficacious after the onset of beta-cell dysfunction and cachexia.
Our results also show PPAR $\gamma$ and RXR agonists are able to prevent weight loss during the later stages of diabetes. Since food consumption did not change, this suggests RXR and PPAR $\gamma$ agonists decreased malabsorption [38], urinary excretion of carbohydrates [39], or metabolic rate (e.g. thermogenesis). Consistent with the latter hypothesis, we recently found PPAR $\gamma$ agonists suppress thermogenesis in adipocytes [40]. Although more work is needed to understand the mechanism underlying the body weight changes, these observations show that treatment with RXR and PPAR $\gamma$ agonists can prevent diabetic cachexia in mice.

Since the biological effects were different for RXR and PPAR $\gamma$ agonists, they should be considered as distinct classes of pharmacological agents. We speculate that perhaps PPAR $\gamma$ agonists are better for controlling serum lipids and RXR agonists better for regulating body weight in diabetic animals. Moreover, combined therapy may provide improved efficacy relative to mono-therapy. A better understanding of the action of RXR and PPAR $\gamma$ agonists should help to optimize their use for treating diabetes while minimizing their side effects.

Acknowledgements. The authors wish to thank J. Lee for her assistance with electron microscopy, M. Osterhout for synthesizing LG100268, V. Styles for synthesizing GW1929 and M. Martin for synthesizing BRL49653. We are also grateful to K. Brown, C. Haffner, E. Hull-Ryde and T. Willson for many useful discussions on this project.

\section{References}

1. Tontonoz P, Hu E, Graves RA, Budavari AI, Spiegelman BM (1994) mPPAR gamma 2: tissue-specific regulator of an adipocyte enhancer. Genes Dev 8: 1224-1234

2. Spiegelman BM (1997) Peroxisome proliferator-activated receptor gamma: a key regulator of adipogenesis and systemic insulin sensitivity. Eur J Med Res 2: 457-464

3. Lehmann JM, Moore LB, Smith-Oliver TA, Wilkison WO, Willson TM, Kliewer SA (1995) An antidiabetic thiazolidinedione is a high affinity ligand for peroxisome proliferator-activated receptor gamma (PPAR gamma). J Biol Chem 270: 12953-12956

4. Lenhard JM, Kliewer SA, Paulik MA, Plunket KD, Lehmann JM, Weiel JE (1997) Effects of troglitazone and metformin on glucose and lipid metabolism: alterations of two distinct molecular pathways. Biochem Pharmacol 54: 801-808

5. Henke BR, Blanchard SG, Brackeen MF et al. (1998) N-(2Benzoyl-phenyl)-(L)-tyrosine PPAR $\gamma$ agonists (1). Discovery of a novel series of potent antihyperglycemic and antihyperlipidemic agents. J Med Chem 41: 5020-5036

6. Fujiwara T, Yoshioka S, Yoshioka T, Ushiyama I, Horikoshi H (1988) Characterization of new oral antidiabetic agent CS-045. Studies in KK and $o b / o b$ mice and Zucker fatty rats. Diabetes 37: 1549-1558

7. Oakes ND, Kennedy CJ, Jenkins AB, Laybutt DR, Chisholm DJ, Kraegen EW (1994) A new antidiabetic agent, BRL 49653, reduces lipid availability and improves insulin action and glucoregulation in the rat. Diabetes 43: 1203-1210 
8. de Souza CJ, Yu JH, Robinson DD, Ulrich RG, Meglasson MD (1995) Insulin secretory defect in Zucker fa/fa rats is improved by ameliorating insulin resistance. Diabetes 44: 984-991

9. Mukherjee R, Davies PJ, Crombie DL et al. (1997) Sensitization of diabetic and obese mice to insulin by retinoid $\mathrm{X}$ receptor agonists. Nature 386: 407-410

10. Mukherjee R, Strasser J, Jow L, Hoener P, Paterniti JR Jr, Heyman RA (1998) RXR agonists activate PPARalpha-inducible genes, lower triglycerides, and raise HDL levels in vivo. Arterioscler Thromb Vasc Biol 18: 272-276

11. Hummel KP, Coleman DL, Lane PW (1972) The influence of genetic background on expression of mutations at the diabetes locus in the mouse. I. C57BL-KsJ and C57BL-6J strains. Biochem Genet 7: 1-13

12. Shafrir, E (1990) Diabetes in animals. In: Rifkin H, Porte D Jr (eds) Diabetes Mellitus, Theory and Practice. Elsevier, New York, pp 299-340

13. Berkowitz K, Peters R, Kjos SL et al. (1996) Effect of troglitazone on insulin sensitivity and pancreatic beta-cell function in women at high risk for NIDDM. Diabetes 45: 1572-1579

14. Shimabukuro M, Zhou YT, Lee Y, Unger RH (1998) Troglitazone lowers islet fat and restores beta cell function of Zucker diabetic fatty rats. J Biol Chem 273: 3547-3550

15. Oosting JD, Hoffmann JJ (1997) Evaluation of an automated photometric fibrinogen assay. Blood Coagul Fibrinolysis 8: $321-326$

16. McKenna MC, Robison WG Jr, Bieri JG (1983) Cellular localization of liver vitamin A in rats given total parenteral nutrition (TPN) solutions intravenously or orally. J Nutr 113: $1176-1186$

17. Bozzola JJ and Russell LD (1992) In: Bozzola JJ, Russell LD (eds) Electron Microscopy Principles and Techniques for Biologists. Jones and Bartlett Publishers, London, pp 64-182

18. Romano MC, Straub KM, Yodis LA, Eckardt RD. Newton JF (1988) Determination of microsomal lauric acid hydroxylase activity by HPLC with flow-through radiochemical quantitation. Analytical Biochemistry 170: 83-93

19. Paulik MA, Lenhard JM (1997) Thiazolidinediones inhibit alkaline phosphatase activity while increasing expression of uncoupling protein, deiodinase, and increasing mitochondrial mass in C3H10T1/2 cells. Cell Tissue Res 290: 79-87

20. Tai TAC, Jennermann C, Brown KK et al. (1996) Activation of the nuclear receptor peroxisome proliferator-activated receptor gamma promotes brown adipocyte differentiation. J Biol Chem 271: 29909-29914

21. el-Hassan AY, Ibrahim EM, al-Mulhim FA, Nabhan AA, Chammas MY (1992) Fatty infiltration of the liver: analysis of prevalence, radiological and clinical features and influence on patient management. Br J Radiol 65: 774-778

22. Lee SS, Pineau T, Drago J et al. (1995) Targeted disruption of the alpha isoform of the peroxisome proliferator-activated receptor gene in mice results in abolishment of the pleiotropic effects of peroxisome proliferators. Mol Cell Biol 15: 3012-3022

23. Aldridge TC, Tugwood JD, Green S (1995) Identification and characterization of DNA elements implicated in the regulation of CYP4A1 transcription. Biochem J 306: 473-479

24. Inzucchi SE, Maggs DG, Spollett GR et al. (1998) Efficacy and metabolic effects of metformin and troglitazone in type II diabetes mellitus. N Engl J Med 338: 867-872
25. Burant CF, Sreenan S, Hirano K et al. (1997) Troglitazone action is independent of adipose tissue. Clin Invest 100: 2900-2908

26. Heinrich J, Balleisen L, Schulte H, Assmann G, van de Loo $\mathrm{J}$ (1994) Fibrinogen and factor VII in the prediction of coronary risk. Results from the PROCAM study in healthy men. Arterioscler Thromb Vasc Biol 14: 54-59

27. Nicodeme E, Nicaud M, Issandou M (1995) Retinoids stimulate fibrinogen production both in vitro (hepatocytes) and in vivo. Induction requires activation of the retinoid $\mathrm{X}$ receptor. Arterioscler Thromb Vasc Biol 15: 1660-1667

28. Lehmann JM, Lenhard JM, Oliver BB, Ringold GM, Kliewer SA (1997) Peroxisome proliferator-activated receptors alpha and gamma are activated by indomethacin and other non-steroidal anti-inflammatory drugs. J Biol Chem 272: 3406-3410

29. Schror K (1995) Antiplatelet drugs. A comparative review. Drugs 50: 7-28

30. Ghazzi MN, Perez JE, Antonucci TK et al. (1997) Cardiac and glycemic benefits of troglitazone treatment in NIDDM. The Troglitazone Study Group. Diabetes 46: 433-439

31. Cominacini L, Garbin U, Fratta Pasini A et al. (1998) Troglitazone reduces LDL oxidation and lowers plasma E-selectin concentration in NIDDM patients. Diabetes 47: 130-133

32. Fonseca VA, Reynolds T, Hemphill D et al. (1998) Effect of troglitazone on fibrinolysis and activated coagulation in patients with non-insulin-dependent diabetes mellitus. J Diabetes Complications 12: 181-186

33. Alegret M, Ferrando R, Vazquez M, Adzet T, Merlos M, Laguna JC (1994) Relationship between plasma lipids and palmitoyl-CoA hydrolase and synthetase activities with peroxisomal proliferation in rats treated with fibrates. Br J Pharmacol 112: 551-556

34. Keller H, Dreyer C, Medin J, Mahfoudi A, Ozato K, Wahli W (1993) Fatty acids and retinoids control lipid metabolism through activation of peroxisome proliferator-activated receptor-retinoid X receptor heterodimers. Proc Natl Acad Sci USA 90: 2160-2164

35. Standeven AM, Escobar M, Beard RL, Yuan YD, Chandraratna RA (1997) Mitogenic effect of retinoid X receptor agonists in rat liver. Biochem Pharmacol 54: 517-524

36. Standeven AM, Beard RL, Johnson AT, Boehm MF, Escobar M, Heyman RA, Chandraratna RA (1996) Retinoidinduced hypertriglyceridemia in rats is mediated by retinoic acid receptors. Fundam Appl Toxicol 33: 264-271

37. Rabelo R, Camirand A, Silva JE (1997) $3^{\prime}, 5^{\prime}$-cyclic adenosine monophosphate-response sequences of the uncoupling protein gene are sequentially recruited during darglitazone-induced brown adipocyte differentiation. Endocrinology 138: 5325-5332

38. D'Costa DF, Price DE, Burden AC (1992) Diabetic neuropathic cachexia associated with malabsorption. Diabet Med 9: 203-205

39. Marcelli D, Spotti D, Conte F et al. (1995) Prognosis of diabetic patients on dialysis: analysis of Lombardy Registry data. Nephrol Dial Transplant 10: 1895-1900

40. Paulik, MA, Buckholz RG, Lancaster ME et al. (1998) Development of infrared imaging to measure thermogenesis in cell culture: Thermogenic effects of Uncoupling protein-2, Troglitazone, and $\beta$-adrenoceptor agonists. Pharmaceutical Research 15: 944-949 